Возняк С. М., к.т.н., с.н.с;

Іващенко А. М., к.т.н., доцент;

Полякова О. В.

Центр воєнно-стратегічних досліджень Національного університету оборони України імені Івана Черняхівського, Київ

\title{
Міжнародно-правова регламентація застосування збройних сил в сучасних воснних конфліктах
}

Резюме. Розглядаються основи формування і використання міжнародно-правової регламентації застосування збройних сил в сучасних воєнних конфліктах, наводяться практичні приклади 3 законодавства США і Російської Федерації (РФ) щодо нормативно-правових питань направлення національних збройних сил для виконання завдань за межами національних територій.

Ключові слова: воєнний конфлікт, збройні сили, нормативно-правова база застосування збройних сил.

Постановка проблеми. Незважаючи на декларативні заяви про перевагу політичних, економічних, дипломатичних та інших засобів в рамках існуючого міжнародно-правового поля, застосування воєнної сили у сучасних воєнних конфліктах не втратило свого значення. Аналіз сучасних конфліктів показує, що воєнне втручання стало нормою. Сучасні воєнні конфлікти та способи застосування воєнної сили характеризуються зниженням ролі права в питаннях врегулювання міжнародних відносин. Актуальним $є$ аналіз практики використання міжнародної нормативно-правової бази при направленні і застосуванні збройних сил у воєнних конфліктах.

Аналіз основних досліджень i публікацій. При проведенні аналізу підготовки даної статті були використані збірники документів 3 міжнародного права [15], законодавчі акти Російської Федерації [67], устави збройних сил США [8-10].

Метою статті $\epsilon$ аналіз міжнародної нормативно-правової бази застосування збройних сил в сучасних воєнних конфліктах.

Виклад основного матеріалу. Міжнародно-правовою основою застосування збройних сил $\epsilon$ норми міжнародного загального і гуманітарного права, закони та звичаї ведення війни (бойових дій), положення міждержавних i союзних (коаліційних) договорів i угод. Стосовно воєнної сфери, міжнародне право визначається як поширення міжнародних угод, правових норм, а також принципів, визнаних більшістю держав, на воєнні операції i бойові дії. Ці положення визначаються Статутом $\mathrm{OOH}$, резолюціями
Ради Безпеки ООН, Гаазькою конвенцією 1907 року, Женевськими конвенціями 1949 року та Додатковими протоколами до них від 8 червня 1977 року та рядом інших. Україна ратифікувала Женевські конвенції у серпні 1954 року, а Додаткові протоколи до них у січні 1990 року [5].

Відповідно до цих документів правове регулювання воєнних конфліктів визначається нормами міжнародного гуманітарного права (МГП). Норми МГП встановлюють закони ведення війни, визначають принцип гуманізації як основоположний, забороняють найбільш жорстокі форми ведення бойових дій, поліпшують долю поранених i хворих, вимагають гуманного поводження 3 військовополоненими, захист мирного населення і цивільних об'єктів.

Так, в ст. 35 Додаткового Протоколу I сформульовано таке положення: “... в разі будьякого збройного конфлікту право сторін, що беруть участь в ньому, вибирати методи і засоби ведення війни не $є$ необмеженим". 3 цього положення випливають два основних правила правового характеру. Перше забороняє застосовувати зброю, снаряди, речовини, а також методи ведення військових (бойових) дій, які за своєю природою можуть викликати зайві руйнування i людські жертви. Друге встановлює різницю між цивільним населенням (цивільними об'єктами) і комбатантами. Ст. 48 вищевказаного протоколу чітко вказує, що сторони конфлікту повинні вести бойові дії тільки проти комбатантів і воєнних об'єктів. При цьому МГП не ставить перед собою мету визначити відповідальність за розв'язання збройних конфліктів. Це відноситься виключно до компетенції ООН. Значна частина норм 
МГП, що регламентують участь національних 3С у воєнних конфліктах, повинна бути закріплена в національному цивільному i військовому законодавстві.

Cmamym OOH заклав правові основи функціонування системи безпеки, яка на даний час розвивається i вдосконалюється. Однією з цілей створення цієї організації було обмеження застосування збройної сили державами в міжнародних відносинах. У зв'язку 3 цим суть одного 3 головних принципів сучасного міжнародного права полягає у виключенні застосування сили або погроз силою 3 практики міжнародного спілкування (п. 4 ст. 2 Статуту $\mathrm{OOH}$ ). Цей принцип доповнюється іншим, не менш важливим: всі міжнародні конфлікти і суперечки повинні вирішуватися тільки мирними засобами (п. 3 ст. 2 Статуту ООН).

Інтегральним аспектом цих положень $€$ принцип невтручання (non-intervention), який передбачає утримання будь-якої держави від втручання у внутрішні справи іншої, тобто повага державного суверенітету.

Аналіз конфліктів свідчить про те, що на практиці не завжди строго дотримуються зобов' язань щодо дотримання цих принципів і норм. Причиною таких порушень $\epsilon$ необхідність вирішення пріоритетних воєннополітичних і воєнно-стратегічних завдань, які відповідають національним інтересам країни, а також виконання союзницьких зобов' язань.

OОН покликана попереджувати i припиняти інциденти, що виникають між державами, в тому числі iз застосуванням збройної сили. Допускаючи можливість виникнення конфліктних ситуацій, міжнародне співтовариство прагне поставити ïх учасників, схильних до вирішення суперечки збройним шляхом, в рамки дотримання правил застосування сили. У преамбулі Статуту ООН проголошується, що народи Об'єднаних Націй ставлять перед собою мету - усунути війни зі сфери міждержавних відносин. Принципи вирішення міжнародних суперечок мирними засобами, що не піддають загрозі міжнародний мир i безпеку, дотримання територіальної недоторканності і політичної незалежності будь-якої держави, які закріплені в ст. 2 Статуту ООН та інших міжнародних документах, спонукають держави утримуватися від застосування та загрози застосування сили.

Винятком $е$ самооборона. Ст. 51 Статуту ООН дозволяє державі-члену цієї організації здійснювати колективну чи індивідуальну самооборону із застосуванням сили тільки у випадку, коли на нього скоєно збройний напад. Необхідно особливо відзначити, що останнім часом спостерігається прагнення розширити поняття “самооборона". При цьому питання про те, якою мірою конкретна ситуація дозволяє говорити про правомірність застосування сили в порядку самооборони, віддається ними на розсуд не тільки Ради Безпеки, а й по суті самих держав. I як наслідок, 3'являються нові концепції "превентивного" і "попереджувального" застосування сили в якості "природного розвитку поняття самооборони”, що дозволяє окремим державам формально законно використовувати ЗС для нанесення превентивних ударів.

Останнім часом також намітилася тенденція необгрунтованого застосування збройної сили при проведенні воєнних операцій без відповідної санкиії Ради Безпеки ООН. Тим самим порушується ключовий елемент Статуту $\mathrm{OOH} \mathrm{-} \mathrm{принцип} \mathrm{незастосування} \mathrm{сили} \mathrm{в}$ міжнародних відносинах. Однак військовополітичне керівництво ряду держав, для обгрунтування застосування своїх ЗС нібито в рамках міжнародного права наводить ряд аргументів, до яких відносяться “особливі повноваження", “виняткові обставини” i “гуманітарне втручання".

Закони ведення війни, яких дотримуються в період збройних конфліктів, як специфічна галузь міжнародного права, містять свої принципи, якими повинні керуватися воюючі сторони. Ці принципи регулюють відносини в період збройних конфліктів міждержавного та міжнародного характеру. Їх можна об'єднати в такі групи:

обмежують воюючих у засобах і методах ведення війни;

захищають жертв війни, законні права комбатантів i некомбатантів, а також права цивільного населення;

забезпечують нейтралітет i відносини воюючих і нейтральних держав.

Специфічним предметом регулювання даної галузі права є як аспекти, що стосуються безпосередньо збройної боротьби (засоби, способи, методи ведення війни, бойових дій), так і опосередковано пов'язані 3 нею (режим поранених, хворих, військовополонених, осіб, які зазнали корабельної аварії, укладання угод про перемир'я , підписання мирних договорів і т. д.). Норми МГП адресовані насамперед збройним силам воюючих сторін, які зобов'язані знати їх і виконувати в своїй практичній діяльності. Вони також мають на 
меті захистити жертви війни і обмежити застосування воюючими державами певних методів і засобів эiі ведення. Існує реальна можливість мінімізації наслідків збройних конфліктів шляхом посилення правових норм, що обмежують свавілля держав-учасників, а також формування інституту юридичної відповідальності держав, їх збройних сил і окремих фізичних осіб за порушення зазначених норм. Однак на практиці така можливість дискредитується в ряді випадків не правовими діями.

Важливий аспект міжнародно-правової бази застосування збройних сил обгрунтування легітимності їх використання за межами національної території.

Військово-політичне керівництво РФ вважає, що для направлення військ за кордон достатньо тільки внутрішнього законодавства. У зв'язку з вбивством 7 липня 2006 року російських дипломатів в Іраку, Рада Федерації РФ прийняла постанову [6], відповідно до якої президенту дозволено направлення підрозділів збройних сил та підрозділів спеціального призначення за межі національної території 3 метою припинення міжнародної терористичної діяльності проти РФ або громадян РФ та осіб без громадянства, які постійно проживають на території РФ.

Після війни з Грузією в серпні 2008 року були внесені зміни в закон РФ “Про оборону”, якими визначено перелік підстав для застосування збройних сил РФ за іiі межами. Підрозділи ЗС РФ можуть бути використані для: відбиття агресії, запобігання агресії проти іншої держави, захисту громадян РФ за кордоном, боротьби 3 піратством, забезпечення безпеки судноплавства, відбиття нападу на збройні сили або інші війська, дислоковані за межами території країни [7].

У США вважається, що правовими основами будь-якого перебування американських військ за кордоном $\epsilon$ міжнародні договори, передбачені ст. 102 Статуту ООН і Віденської конвенції про право міжнародних договорів від 23 травня 1969 року. Ці договори повинні відповідати загальновизнаним принципам і нормам міжнародного права, гарантувати повагу суверенітету держав, що приймають війська, дотримання іноземними військами національного законодавства, традицій, невтручання у внутрішню і зовнішню політику цих країн, незастосування проти них сили або загрози силою.

Питання відповідальності за незаконне застосування збройних сил регламентуються
"Кодексом поведінки, щзо стосуються військово-політичних аспектів безпеки" (Code of Conduct on Politico-Military Aspects of Security) 1994 року [8], які спрямовані на розв'язання проблеми у зміцненні довіри, але, порівняно 3 Віденським документом, йому бракує механізмів верифікації. Так, дотримання Кодексу поведінки під час конфлікту на сході України оцінити важко через невизначеність статусу сил самопроголошених ДНР і ЛНР. Хоча Уряд Росії не заперечує, що російські громадяни воюють разом зі збройними підрозділами на сході України, цих осіб називають добровольцями, i на їх формі не має розпізнавальних знаків належності до ЗС РФ [9]. Ст. 31 даного документа закріплює наступні принципи: “Держави-учасники будуть забезпечувати положення, щоб особовий склад збройних сил, наділений командними повноваженнями, здійснював їх в рамках національного законодавства та міжнародного права, а також щоб він був обізнаний про те, що згідно з цими правовими нормами він може притягуватися до індивідуальної відповідальності за протизаконне здійснення таких повноважень. Накази, що суперечать національному законодавству i міжнародним правам, віддаватися не повинні. Відповідальність вищих осіб ні в якій мірі не звільняє підлеглих від їх власної відповідальності".

На практиці в разі проведення операцій в особливих умовах мирного часу, і перш за все міжнародних (коаліційних) під егідою ООН, виходять в правовому відношенні з вимог, так званого, оперативного права. Це поняття визначається як сукупність юридичних принципів і норм міжнародного, внутрішнього права, а також права інших іноземних держав, які безпосередньо впливають на ведення воєнних операцій. В рамках даного права використовуються конкретні деталізовані документи оперативного характеру, що враховують загальні положення і вимоги інших міжнародно-правових документів. До їх числа відносяться: мандат ООН, "Угода щодо статусу 3С”, “Угода по завданням" і "Правила застосування сил".

Мандат ОOH (UN Mandate) - це резолюція Ради Безпеки або Генеральної асамблеї, яка надає міжнародну підтримку (проведення) миротворчих операцій в формі залучення багатонаціональних контингентів під егідою ООН, а також визначає політичну мету і конкретних учасників таких операцій. Термін діï мандата обмежений і вимагає продовження РБ або Генеральною асамблеєю ООН. У 
правовому відношенні мандат надає країнамучасницям міжнародної операції юридично законне право застосування збройних сил. Мандат містить перелік таких питань: основна мета операції, роль, завдання і функціональні обов'язки залучених військових контингентів, склад i організація цих сил, призначення командувача силами ООН і визначення його юридичної і функціональної відповідальності, органи, відповідальні за нагляд i правовий контроль операції, юридична та функціональна відповідальність органів ООН і національних органів учасників операції, права, пільги i принципи недоторканності міжнародних сил учасників операції, терміни та умови, на яких країна перебування згодна на присутність сил ООН, термін дії мандата OOH.

“Угода щуодо статусу збройних сил” (Status of Forces Agreement) $є$ міжнародним документом, який визначає юридичну i функціональну відповідальність (обов'язки) збройних сил, які розгорнуті або перебувають за кордоном на постійній основі, тобто їх правовий статус і легітимність перебування на території іншої держави. Ця угода може являти собою договір або меморандум про взаєморозуміння, що укладається між ООН в особі Секретаріату і країною перебування в разі проведення операцій під егідою міжнародної організації. На відміну від мандата ООН цей документ не вимагає постійного відновлення і за домовленістю між сторонами $є$ фактично постійно діючим правовим документом. Така Угода регулює питання відносин між військовими структурами, цивільною владою і населенням країни перебування.

У разі проведення міжнародних операцій поза мандатом ООН така угода може складатися індивідуально між країноюконтрибутором i країною перебування, або, якщо не потрібно обов'язкової згоди на воєнну присутність в країні перебування, взагалі не розглядатися.

"Угода щодо статусу збройних сил" охоплює такі основні питання: здійснення контрольних та владних повноважень в зоні дії збройних сил, свобода пересування i миротворчі дії в зоні операції, регламентація матеріального i фінансового забезпечення, використання засобів забезпечення країни перебування (зв'язок, водо- i електропостачання, аеропорти, морські порти та ін.), забезпечення права недоторканності: захист від насильницького захоплення або затримання особового складу, приміщень, документів або їх перегляду, канали взаємодії і зв'язку між військовим командуванням i місцевою владою країни перебування, залучення місцевого цивільного персоналу, використання символіки (прапори, розпізнавальні знаки та ін.), процедури вирішення спірних питань і розбіжностей.

У правовому плані ключовим моментом вищерозглянутого документа $є$ регламентація цивільної та кримінальної відповідальності особового складу 3С. Якщо в ньому не міститься спеціальна домовленість, то особовий склад воєнного контингенту несе цивільну та кримінальну відповідальність відповідно до законів, традицій (звичаїв) i процесуального кодексу країни перебування. При виникненні труднощів командувач (командир) цим контингентом зобов'язаний консультуватися зі своєю військовоюридичною службою i представником посольства (консульства).

"Правила застосування сил" (Rules of Engagement) визначаються як: “директивні вказівки уряду i воєнного керівництва, які встановлюють умови і обмеження, при яких застосовуються збройні сили і починаються або продовжуються бойові дії проти сил противника".

Основні цілі “Правил ...” поділяються на політичні, воєнні та правові. Політичні цілі визначаються директивними вказівками до командувачів (командирів) залучених воєнних формувань.

Воєнні цілі визначають параметри, в рамках яких командувач (командир) повинен діяти в інтересах вирішення поставлених завдань. Крім того, ці цілі передбачають: визначення масштабу i рівня операції, що проводиться 3 метою уникнення небажаної ескалації бойових дій, регламентацію можливостей командування впливати на хід бойових дій, забезпечення при необхідності зміщення (переорієнтування) акцентів вирішуваних завдань.

Правові цілі визначають обмеження на дії залучених угруповань військ (сил) в інтересах ix відповідності як внутрішньому законодавству, так і міжнародному праву. Слід зазначити, що обмеження, які вводяться, можуть носити навіть більш жорсткий характер, ніж це передбачається внутрішніми і міжнародними законами. Крім того, правові цілі і особливо обмеження можуть ув'язуватися 3 вмістом відповідних резолюцій РБ ООН, що найбільш характерно при проведенні миротворчих операцій. 
Загальною основою для розробки $\mathrm{i}$ використання вищевказаного документа в усьому діапазоні проведення військових операцій (від мирного часу до стану війни) $є$ інструкція комітету начальників штабів (КНШ) "Постійно діючі правила застосування сил" (CJCS Standing Rules of Engagement). Зазначений документ являє собою практичний посібник із застосування збройних сил i використання права на самооборону (визначає його рамки). У сфері оперативного права "Постійно діючі правила застосування сил" поширюються на всі операції і надзвичайні ситуації за межами США, а всередині країни на повітряні i морські операції, що проводяться в рамках забезпечення внутрішньої безпеки.

В сучасних умовах часто проводяться багатонаціональні операції (multinational environment). При цьому 3 санкції міністра оборони розробляється спеціальний документ "Правила застосування сил в умовах багато національності" (Multinational Rules of Engagement) або використовуються "Правила ..." КНШ. У будь-якому випадку ЗС зберігають право на самооборону у відповідь на ворожий акт або прояв загрози. При діях у складі міжнародної військової коаліції в рамках “Правил ...” створюються єдині загальні правові основи ведення операцій об'єднаним угрупуванням.

Вищерозглянуті документи містять такі конкретні нормативно-правові положення i вимоги: всі военні операції ведуться в рамках законів і правил ведення війни, застосування военної сили розглядається лише як останній, винятковий засіб, ніщо не обмежує права командувача (командира) вживати всіх необхідних і адекватних заходів в інтересах самооборони (самозахисту), війська можуть відкривати у відповідь вогонь у разі вогневого впливу протилежної сторони або наявності чіткої ознаки ворожого наміру чи скоєння ворожої дії [10]; в разі нападу на війська неозброєних цивільних елементів або заколотників командування повинно використовувати мінімум сил в залежності від обстановки i адекватно до загрози; забороняється захоплення чужої власності для виконання поставленого завдання; затримання цивільних осіб дозволяється лише в цілях безпеки або самооборони.

Документ визначає, коли і як можуть бути застосовані виділені сили, відображає закони і правила ведення операцій, вимоги оперативної обстановки і містить обмеження на використання військової сили. Крім того, в правовому відношенні, за оцінкою американських фахівців, він $\epsilon$ головним засобом доведення командувачем (командиром) до своїх підлеглих правових, політичних, дипломатичних i військових вказівок. У зв'язку 3 цим “Правила ...” обов' язково включаються в оперативний план і бойові накази. Слід підкреслити, що цей документ ретельно розглядається військовоюридичною службою, має несекретний гриф і в скороченому варіанті (включає тільки основні нормативні положення) видається особовому складу контингенту у вигляді спеціальних текстуальних карток 3 тим, щоб військовослужбовці неухильно дотримувалися основні положення і вимоги, що містяться в ньому.

В цілому, всі види "Правил застосування сил" є головним інструментом регулювання, в тому числі правового, застосування ЗС, що робить ці документи фундаментальними засадами дотримання оперативного права.

Крім вищерозглянутих документів, юридична основа проведення міжнародних операцій 3 залученням $3 \mathrm{C}$ формується директивами генерального секретаря $\mathrm{OOH}$, “директивними розробками ООН” i директивою командувача миротворчими силами ООН.

Директива генерального секретаря $\mathrm{OOH}$ (UN Sec Gen Directive) є офіційним письмовим документом, який направляється командувачу міжнародними силами $\mathrm{OOH}$, і визначає загальні умови і процедури застосування миротворчих сил і проведення миротворчих операцій.

Директиви ОOH (UN Regulations), які готуються в рамках і на виконання директиви генерального секретаря ООН, включають такі основні питання: загальні положення проведення операції, а також використовувана термінологія і поняття; сфера відповідальності командувача миротворчими силами (управління, зв'язок, командування, передача повноважень, дисциплінарна практика, взаємодія 3 військовою поліцією); права, обов' язки та відповідальність особового складу щодо місцевих законів, поведінки і юридичної захищеності, інформаційне забезпечення особового складу 3 правових питань; перелік ключових положень і вимог міжнародних угод, що регламентують дану операцію; міжнародна символіка, пільги, правової імунітет.

Директива командувача миротворчими силами ООН (Force Commander's Directive), що розробляється на основі вищевказаних документів $\mathrm{OOH}, \epsilon$ оперативним документом, який регламентує проведення даної операції за 
участю багатонаціональних військових контингентів.

У зв’ язку зі специфікою кожної операції зазначені директиви можуть відрізнятися, але їх спільною основою $є$ наступні аспекти: командно-штабні можливості; організаційна структура; ведення операції (цілі, завдання, задум, план реалізації та ін.); правове забезпечення; інформаційне забезпечення; ведення повітряних операцій; тилове i фінансове забезпечення операції; зв'язок 3 ООН і громадськістю.

Слід особливо підкреслити, що міжнародно-правове поняття і збройні сили розділене 3 внутрішньодержавним поняттям i тлумачиться ширше. Проте така різниця допускається віденською Конвенцією про право міжнародних договорів 1969 року, однак практика показує, що відмінності в поняттях призводять часом до нерозуміння тією чи іншою стороною договору окремих ii положень, особливо в тих випадках, коли в міжнародному договорі будь-які поняття чітко не визначені. Зокрема, п. 3 статті 43 I Додаткового протоколу до III Женевської конвенції містить положення, відповідно до якого сторона конфлікту, в разі включення в свої збройні сили напіввійськової або збройної організації, яка забезпечує охорону порядку, зобов'язана повідомити про це інші сторони конфлікту. Порушення зазначеної процедури може мати негативні наслідки для особового складу напіввійськових формувань, який може втратити свій привілейований статус в полоні i переслідуватися за кримінальним законодавством, утримуватись у полоні державою за участь у військових діях.

Практика застосування 3С у сучасних умовах в рамках проведення міжнародних (коаліційних) воєнних операцій (операції в зоні Перської затоки, в Іраку, Афганістані, Лівіiі) виявила необхідність особливої уваги до міжнародно-правових аспектів операцій. У зв'язку 3 цим намітилася стійка тенденція створення об'єднаних міжнародних юридичних груп.

Поряд 3 основними правовими документами міжнародного співтовариства важливим елементом міжнародно-правової бази застосування національних ЗС $є$ дво- i багатосторонні міжнародні угоди. До їх числа відносяться договори про заборону i поширення зброї масового знищення, ракетноядерних технологій, використання протипіхотних мін та розмінування в зонах військових конфліктів, розробки i застосування запалювальних боєприпасів i лазерної зброї і ін. Однак необхідно особливо підкреслити, що ряд таких міжнародних угод або не підписані окремими країнами, або не ратифіковані парламентом.

Разом 3 тим необхідно відзначити, що багато положень вищевказаних міжнародних угод i конвенцій включені до статутів i настанов ЗС США, які регламентують правові аспекти їх застосування та ведення військових операцій [11-13].

Висновки. До проблемних аспектів застосування МГП в сучасних воєнних конфліктах можна віднести наступні:

не відповідність основоположних норм, що стосуються застосування $3 \mathrm{C}$ за межами національних територій;

недостане регулювання правового співробітництва держав при здійсненні миротворчої діяльності;

норми МГП не імплементуються в національне право, не поширюються i практично не застосовуються в збройних силах держав;

нові види зброї, що розробляються або придбаються і приймаються на озброєння, не відповідають вимогам МГП і міжнародним договорам;

не визначені питання, що стосуються завдань і порядку застосування військ, які не входять до складу ЗС держав,

не визначенні чіткий порядок i форми використання останніх при виникненні воєнного конфлікту.

У подальшому буде розглянута особливості застосування міжнародного права в гібридних конфліктах.

\section{СПИСОК ВИКОРИСТАНОЇ ЛІТЕРАТУРИ}

1. Женевские конвенции от 12 августа 1949 года и Дополнительные протоколы к ним. - М., МККК, 1997 $-320 \mathrm{c}$.

2. Международное право. Ведение военных действий. Сборник Гаагских конвенций и иных соглашений. М., МККК, 1999. - 335 c.

3. Мулинен Ф. Право войны. Руководство для вооруженных сил. - М., МККК, 1993. - 318 с.

4. Воєнні аспекти міжнародного права. Навчальний посібник / Під заг. ред. В.Б. Толубка-К., Азимуг, 2004. $240 \mathrm{c}$.

5. Міжнародне гуманітарне право. Навчальний посібник /Під заг. ред. В.П. Базова. - К. : Варта, 2000 - 176 с.

6. Постановление Совета Федерации Федерального Собрания Российской Федерации от 7 июля 2006 года № 219-СФ “Об использовании формирований Вооруженных Сил Российской Федерации и подразделений специального назначения за пределами территории Российской Федерации в целях пресечения международной террористической 
деятельности" // Собрание законодательства Российской Федерации. 2006. № 29. Ст. 3144.)

7. Стаття 10 Закону РФ "Про оборону” .

8. OSCE, Code of Conduct on Politico-military Aspects of Security, DOC/FSC/1/95, 3 Dec. 1994, http://www.osce.org/fsc/41355.

9. Flintoff, C., Russia reports troop deaths in Ukraine, but calls them "volunteers". National Public Radio, 8 Sep. 2014 , http://www.npr.org/blogs/parallels/2014/09/08/346735504/s ome-in-russia-admit-their-troops-volunteer-in-ukraine.

10. Під ворожим наміром мається на увазі загроза негайного застосування сили іншою іноземною державою, терористичною групою або окремими особами; під ворожими діями розуміються дії збройних сил, направленні на припинення або утруднення виконання завдань i/aбо зобов'язань союзницьких військ;

11. Статут 3С США JP 1-02 "Словник військових та пов’ язаних з ними термінів МО”.

12. Статут СВ ЗС США FM 1-04.10 “Закон ведення наземних бойових дій"

13. Статут СВ ЗС США FM 1-04 "Правове забезпечення (підтримка) військових операцій”, Статут ЗС США JP 1-04 “Об’ єднане правове забезпечення (підтримка) військових операцій”

Стаття надійшла до редакції 17.03.2017

Возняк С. Н., к.т.н., с.н.с;

Иващенко А. М., к.т.н., доцент;

Полякова Е. В.

Центр военно-стратегических исследований Национального университета обороны Украины имени Ивана Черняховского, Киев

\section{Международно-правовая регламентация применения вооруженных сил в современных военных конфликтах}

Резюме. Рассматриваются основы формирования и использования международно-правовой регламентации применения вооруженных сил в современных военных конфликтах. Приводятся практические примеры из законодательства США и Российской Федерации по вопросам направления национальных вооруженных сил для выполнения задач за пределами национальных территорий.

Ключевые слова: военный конфликт, вооруженные силы, военные операции, нормативно-правовая база применения вооруженных сил.

\section{A. Ivashchenko, Ph.D;}

S/ Voznyk, Ph.D;

E/ Polyakova

Center for Military and Strategic Studies National Defence University of Ukraine named after Ivan Chernyhovsky, Kyiv

International legal regulation of the use of armed forces in modern military conflicts

Summary. The principles of formation and use of international legal regulation of the use of armed forces in modern military conflicts are considered. Practical examples are given from the legislation of the United States and the Russian Federation on the direction of national armed forces to carry out tasks outside national territories. forces.

Key words: military conflict, armed forces, military operations, regulatory framework for the use of armed 